http://jmscr.igmpublication.org/home/

ISSN (e)-2347-176x ISSN (p) 2455-0450

crossref DOI: https://dx.doi.org/10.18535/jmscr/v7i12.80

Journal Of Medical Science And Clinical Research

\title{
A study on Salzmann's Nodular Lt. Eye Degeneration
}

\author{
Authors \\ Dr Kamla Prasad M.S. $\left(\right.$ Optholmology) ${ }^{1}$, Dr Rajesh Paswan M.D. $\left(\right.$ Radio Diagnosis) ${ }^{2}$, \\ Dr Rahmat Ali* Mch (Ortho), MS (Ortho) ${ }^{3}$ \\ ${ }^{1}$ Consultant Eye Surgeon, Pt. Kamlapati Tripathi District Hospital, Chandauli \\ ${ }^{2}$ Associate Prof. \& H.O.D. (Radiology), Maharshi Vashisth Autonomous Govt. Medical College-Basti \\ ${ }^{3}$ Associate Prof. \& H.O.D. Ortho, Maharshi Vashisth Autonomous Govt. Medical Collage-Basti \\ *Corresponding Author \\ Dr Rahmat Ali Mch (Ortho), MS (Ortho)
}

\begin{abstract}
Salzmann's Nodular Degeneration (SND) is a condition where a small growth like nodule forms on front surface of cornea disease progress slowly and measures 1-4 mm which is located on anterior to bowman's layer of cornea. These are gray white to bluish in colour. Nodules are removed by superficial keratectomy under topical anaesthesia.
\end{abstract}

Keywords: Salzmann, Nodule, Callus, Bowman's layer, Cornea, Keratectomy, topical anaesthesia, Slit lamp.

\section{Introduction}

Salzmann's Nodular Degeneration (SND) is a condition where a small 'growth' callus like noduleforms on frontal surface of cornea. Its progress is slow and usually located on anterior to bowma's layer of cornea. Nodules are usually of gray-white to bluish in colour. This disease is usually bilateral and no diurnal variation in vision is seen. There is no benefit with spectacle.

\section{Incidence}

Incidence is more in females than males but exact ratio is not known.

\section{Etiology}

Etiology is not very clear. It is not associated with trauma,xposure to toxic materials to the eye and use of contact lences. It has no association with systemic disease.

\section{Predisposing Factor}

Chronic inflammatory conditions of cornea acts as predisposing factor.

\section{Pathology}

There are multiple flakes present on eyelashes of both eyes and most affected eye shows waxy secretions over lid margins. Greyish-white nodules are usually present on cornea like callus of uniting bone, especially between the corneal epithelium and Bowman's layer. Other ocular examinations including fundus is normal. 


\section{Histopathology}

Histological examination shows corneal epithelium overlying the nodule was atrophic and hyalinised fibrous plaque was present between epithelium and bowman's layer. On periodic acid Schiff stain the epithelial basement membrane was thickend and irregular.

\section{Diagnosis}

Diagnosis of salzmann's nodules degeneration (SND) is done on basis of presentation of nodules on slit lamp examination. There is gradual deterioration of vision and progressive increase irregular astigmatism.

\section{Case Report}

45 year old female came in eye OPD with 4 years history of painless with gradnal loss of vision in both eyes. The diminution of vision was more in left eye than right eye. Pt. had also symptoms of itching, foreign body sensation and photophobia in left eye. She had changed spectacle many times but problem was not eliminated. There was no variation of vision in day and night. There was no $\mathrm{h} / \mathrm{o}$ neither systemic disease nor local history like trauma and exposure of foreign materials to the eye. Visual acuity in Rt eye was 6/24 while in left eye was 5/60. On slit lamp examination, there were multiple flakes present on eye lashes of both eyes and Lt eye showed waxy secretions over the lid margins. Greyish-white nodules were present on cornea between corneal epithelium and Bowman's layer. Other ocular examinations including fundus was normal.

\section{Treatment}

The main treatment of SND is superficial keratectomy. Pre operative oral and topical antibiotic started. Before surgery location and extent of the nodules indentified with the help of microscope and slit lamp. Pt. Was prepared and topical anesthesia was administered in left eye. With blade and assistance of alcohol epithelial debridement was done. Once plane of dissection became visible the nodule was peeled off by pulling the edge towards periphery. Dissected tissue was sent for histopathological examination. After removal of nodule topical antibiotic was applied and contact lens was placed. To induce reepithilialization topical steroid was tapered over a period of one month.

\section{Discussion}

Salzmann's nodular degeneration is reported as bilateral degeneration of cornea. Nodules are usually present over cornea. Its colour is usually bluish-grey or white. It is usually elevated above the corneal surface. Pts are usually asymptomatic but in acute stage pain, redness and photophobia are present. Light microscopy shows hayalinized dense deposits. Collagen fibres arranged irregularly infront of broken and sometimes absent Bowman's layer. Surgical removal of nodules and medical management are main basis of treatment of SND.

\section{Conclusion}

Salzmann's nodular corneal degeneration is non inflmatory condition. It is like callus of uniting bones. Females suffer more than males. Chronic inflmatory condition of cornea acts as predisposing factor. It causes slow diminution of vision and progressive irregular astigmatism. Nodule is confirmed by slit lamp and histopathological examination. Surgical removal is the basis of treatment.

\section{References}

1. Roszkowska AM, Aragona P, Spinella R, Pisani A, Puzzolo D, Micali A. Morphologic and Confocal Investigation on Salzmann Nodular Degeneration of the Cornea.

2. Salzmann M. Uebereine Abart der knoetchenfoermigen Hornhautdystrophie. Zeitschriftfuer Augenheilkunde.

3. Hamada S, Darrad $\mathrm{K}$, McDonnell P. Salzmann's Nodular Corneal Degeneration: Clinical Findings, Risk Factors, Prognosis and the Role of 
Previous Contact Lens Wear. Contact lens and Anterior Eye.

4. Eberwein P, Hiss S, Auw-Haedrich C, Sundmacher R, Hauer K, Boehringer D, Meier P, Reinhard T. Epithelial Marker Expression in Salzmann Nodular Degeneration Shows Characteristics of Limbal Transient Amplifying Cells and Alludes to an Involvement of the Epithelium in its Pathogenesis. Acta Ophthalmologica.

5. Das S, Link B, Seitz B. Department of Ophthalmology, University of ErlangenNurnberg, Erlangen, Germany; and ECOS Eye Hospital Berhampur, Orissa, India. Salzmann's Nodular Degeneration of the Cornea: A Review and Case Series Cornea.

6. Yoon KC, Park YG. Recurrent Salzmann's Nodular Degeneration. Jpn J Ophthalmol.

7. Graue-Hernández EO, Mannis MJ, Eliasieh K, Greasby TA, Beckett LA, Bradley JC, Schwab IR. Salzmann Nodular Degeneration. Cornea. 2010;29 (3): 283-9.

8. Jump up $\uparrow$ Lange AP, Bahar I, Sansanayudh W, Kaisermann I, Slomovic AR. Salzmann Nodules-a Possible New Ocular Manifestation of Crohn's Disease: a case report.

9. Carroll JN, Maltry AC, Kitzmann AS. Salzmann's Nodular Corneal Degeneration: 62-year-old woman presents with 3 years of progressive decrease in vision. Eye Rounds.org. September 9, 2013; available

10. Severin M, Kirchhof B. Recurrent Salzmann's Nodular Degeneration. Graefes Arch ClinExpOphthalmol.

11. Müller LJ, Pels L, Vrensen GF. Ultrastructural Organization of Human Corneal Nerves. Invest Ophthalmol Vis Sci.

12. Meltendorf C, Bühren J, Bug R, Ohrloff C, Kohnen T. Correlation Between Clinical in Vivo Confocal Microscopic and Ex Vivo Histopathologic Findings of Salzmann Nodular Degeneration.

13. Ocular Pathology Atlas. American Academy of Ophthalmology

14. Stone D, Astley R, Shaver R, Chodosh J. Histopathology of Salzmann Nodular Corneal Degeneration.

15. Khaireddin R, Katz T, Baile R, Richard G, Linke SJ. Superficial Keratectomy, PTK, and Mitomycin $\mathrm{C}$ as a Combined Treatment Option for Salzmann's Nodular Degeneration: A Follow-up of Eight Eyes. Graefe's Archive for Clinical and Experimental Ophthalmology.

16. Farjo AA, Halperin GI, Syed N, Sutphin JE, Wagoner MD. Salzmann's Nodular Corneal Degeneration Clinical Characteristics and Surgical Outcomes. 